\title{
Philippians 4:1-9 from a rhetorical perspective
}

A H Snyman

(University of the Free State)

\section{ABSTRACT}

\section{Philippians 4:1-9 from a rhetorical perspective}

The aim of this article is to analyse Philippians 4:1-9 from a rhetorical perspective that differs from the typical approach of researchers, who tend to force ancient rhetorical categories on the letter. Using a text-centred approach, it is argued that the dominant rhetorical strategy in this section could be described as: "Urging the Philippians to live the gospel". The section is divided into three phases, namely 4:1 (commanding the Philippians to stand firm for the sake of the gospel); 4:2-3 (calling on certain individuals to be united in their work for the gospel); and 4:1-9 (commanding the Philippians to practise certain key characteristics of the Christian life). The section and its phases are demarcated by rhetorical considerations.

In analysing the rhetorical strategies and techniques in 4:1-9 the focus is on the way Paul argues, on the type of arguments he uses and on the rhetorical techniques that could enhance the impact of his communication. All these strategies and techniques serve to persuade the Philippians to live the gospel, in response to a situation where they were experiencing serious problems and were tempted to abandon their struggle.

\section{INTRODUCTION}

Philippians has been a subject of much discussion among scholars who base their analyses upon the Roman rhetorical tradition. The first major rhetorical analysis of the letter as a whole was by Duane Watson (1988), followed by that of Bloomquist (1993), Witherington (1994), Black (1995) and others. The wide diversity among them throws into serious doubt the theoretical justification for employing categories of classical rhetoric to the Pauline letters.

Watson follows Betz (1979) in his approach to rhetorical analysis. According to him (1988:77-79), 4:1-20 is the peroratio of the letter, with 4:1-9 the so-called repetitio part thereof. Using the same approach, Bloomquist (1993:72-138) reduces the peroratio to 4:8-20, while Witherington (1994:63) identifies 4:4-20 as the 
peroratio. For Black (1995:48) again, it is 4:1-9 and for Schenk (1984:280) 4:1-3, 8-9. This wide variety of divisions is one of the main reasons for identifying Paul's rhetorical strategy from the text itself, rather than using a rhetorical model from outside.

A recent proposal for reconstructing Paul's rhetorical strategy from the text is to be found in the publication of Francois Tolmie: Persuading the Galatians (2005). The purpose of this article is to analyse Philippians 4:1-9 in terms of his proposal for rhetorical analysis. Firstly, Tolmie's proposal will be summarised, followed by a description of the rhetorical situation that called forth the letter. This is followed by an analysis of 4:1-9, which includes (amongst others) a motivated demarcation of the section and its three phases, all based on rhetorical considerations. The main findings of the study are summarised in the conclusion.

I hope to prove that Paul's rhetorical strategy in 4:1-9 can be reconstructed from the text itself, without forcing a model from outside on the letter.

\section{TOLMIE'S PROPOSAL FOR RHETORICAL ANALYSIS}

In his first chapter Tolmie (2005:36-39) explains the approach he followed in analysing the letter to the Galatians. After constructing the rhetorical situation, that is the broad outline of what Paul wants to achieve in the letter as a whole, he formulates his "minimal theoretical framework", consisting of the following aspects:

- The identification of the dominant rhetorical strategy in a particular section by answering two questions: How can one describe Paul's primary rhetorical objective in the section?, and: How does he attempt to achieve this objective?

- The analysis of the section by focussing on the type of arguments Paul uses and why they are effective, or by describing the way he argues to persuade his audience.

- The identification of the rhetorical techniques used to enhance the impact of his communication.

- A description of the way in which the argument of the letter as a whole has been organized. Of course, this aspect can only be addressed once the analysis of the whole letter has been completed. (For a detailed exposition of his proposal, see Tolmie 2000:122-123 and 2005:36-39.) 
In order to understand Paul's rhetorical strategy one must first understand what he is saying to his audience. Thus, exegetical issues need to be addressed, especially when there is no agreement on the meaning of a specific phrase or expression. The focus, however, is on the rhetorical impact of the exegetical issue and not the issue as such.

\section{RHETORICAL SITUATION}

According to commentators like Hendriksen (1962:9-20), Müller (1976: 13-14) and Matter (1976:11) the situation that called forth the letter was the gift that Paul received from the Philippians through their emissary Epaphroditus. The gift was a clear sign of the deep personal relationship between Paul and the church at Philippi, and Marshall (1987:35-69), White (1990:210-215), Stowers (1991:105121) and Brown (1997:486) regard the maintenance of this friendship as the main motivation for the letter.

In his attempt to find structural parallels between the papyri and the letter to the Philippians, Alexander (1995:240) concludes that Philippians “is a 'Verbindungsbrief', adapted and expanded by Paul and employed with the primary purpose of strengthening the 'family' links between the apostle and the Christian congregation in Philippi”. Especially in chapters 1 and 2 Paul is trying to strengthen this close relationship by informing the Philippians about his own position and expressing his need for news about their welfare ("so that I may hear of you that you stand firm...”, 1:27). The exchange of news in order to maintain their relationship is - according to Alexander - the main point of the letter.

That the letter has undertones of friendship and close personal ties is clear from its very beginning $(1: 3-4,7,8)$. The very personal way in which Paul addresses his audience throughout as "my brothers" (1:12; 3:1, 13, 17; 4:18) and "my dear friends" (in 2:12), as well as the numerous features of "friendship letters" from the Greek and Roman world found in the letter (Fee 1995:2-15 and Fitzgerald 1996) all support this view. However, in his construction of the situation in Philippi Silva (1988:21) comes to a different conclusion. He argues "that the Philippians were facing great adversity, had lost their sense of Christian joy and were tempted to abandon their struggle”. The believers in Philippi were experiencing a lack of unity and many of them had lost their confidence in maintaining their Christian confession. Consequently, Paul responded by encouraging and (where necessary) trying to persuade them to stand fast and to 
persevere (For a detailed description of the context of the letter, see Silva 1988:1-10).

O’Brien (1991:36-38) and Fee (1995:32) are in agreement with Silva's focus on the situation in Philippi. Fee (1995:29), for example, finds the occasion of the letter in both friendship and its "hortatory sections", which are case-specific to the situation in Philippi. The reason for the exhortations is the suffering of the Philippians as the result of opposition and especially internal unrest, on which he remarks: "The Philippians are in a life-and-death struggle for the gospel in Philippi, and if their present unrest goes uncorrected, it could bid fair to blunt, if not destroy, their witness to Christ in their city. There can be little question that this issue lies behind the major moments in the letter" (Fee 1995:32).

I find this construction of the situation convincing, since it covers various aspects of the church life in Philippi. The letter must be seen as a response to not just one, but to a variety of problems facing the Philippians, including the threat of the opponents, a lack of Christian joy, internal unrest and disunity. Even if one does not accept this construction, the broad picture remains the same: the letter is dominated by Paul's attempt to persuade and/or encourage his fellow-Christians, with whom he had a deep personal relationship, to persevere in living and proclaiming the gospel amidst all their problems. In 1:27 Paul states quite explicitly that "the one thing" (momon) that matters to him in writing the letter, is that the Philippians' "way of life should be worthy of the gospel of Christ, so that whether I come and see you or am absent, I may hear of you that you stand firm in one spirit, with one mind striving together for the faith of the gospel”.

The rest of the article will be devoted to an analysis of the way in which Paul tries to persuade his audience to live the gospel in 4:19.

\section{ANALYSIS OF PHILIPPIANS 4:1-9}

\subsection{Introduction}

Before Paul's rhetorical strategy in this section is discussed, the following issues need attention:

- Scholars do not agree as to the integrity of the letter to the Philippians: Is it a single letter or a compilation of several letters, written over a period of time? One of the reasons 
offered for the latter is the close link between 3:1 and 4:4 (both calling on the Philippians to rejoice, in line with the friendly tone of the letter), as over and against the harsh tone of 3:24:3, which was supposedly interpolated at a later stage. There is, however, no compelling reason to doubt the integrity of the letter on this, or any other, ground, as Hawthorne (1983:1215), Silva (1988:14-16), Osiek (2000:16-21) and others have argued convincingly. For every argument in favour of composite authorship, there seems to be one against it. As a consequence, Philippians will be treated as a single letter.

- Upon this assumption, 4:1 can (structurally) be viewed as a transition verse. It does refer back to $3: 17-21$, or $3: 1-21$, or even 1:27-3:21, but not exclusively back (as Vincent 1961: 129; Hendriksen 1962:189; Müller 1973:185-6; and Thurston and Ryan 2005:135 commented). Nor does it only point forward, as Lohmeyer (1974:163-5) suggested. Phil 4:1 is transitional, concluding the previous discussion (1:27-3:21) and preparing for the various commands in 4:1-9 (For this view - and its motivation from a structural perspective - see Loh and Nida 1977:123; O’Brien 1991:473, 476; Fee 1995:385-6; and Osiek 2000:107).

- $\quad$ But why divide the text between 3:21 and 4:1, and not between 4:1 and 4:2 (as Silva 1988:219 does), or between 4:3 and 4:4 (as Fee 1995:400 suggests)? As this is a rhetorical study, the principle used for demarcating sections is whether a change in rhetorical strategy can be detected or not (Tolmie 2005:29). Thus, one must ask whether there is a change in strategy between chapters 3 and 4 , and somewhere in chapter 4 . The main reason for dividing the text between $3: 21$ and $4: 1$ is the sudden high pitch of emotion in 4:1, which represents a shift in Paul's rhetorical strategy. It reveals the love and affection with which he is about to instruct the Philippians in 4:1-9. The asyndeta in 4:1-9 also indicate that these verses belong together. The instructions end at 4:9 and in 4:10-20 Paul changes to a narrative on the gift that he received from the Philippians. In sum: the sudden emotional tone in $4: 1$, the list of instructions in 4:1-9 and the asyndeta used in this section all justify a break between 3:21 and 4:1, while the change from a list of instructions to a narrative (with its links) supports a break between $4: 9$ and 4:10. 
- The dominant rhetorical strategy in 4:1-9 can be described as: "Urging the Philippians to live the gospel". The section can be divided into three phases: 4:1, 4:2-3 and 4:4-9. Reasons for the first division are, firstly, the change from command in $4: 1$ to requests in 4:2-3; and secondly, the list of endearing terms in $4: 1$, not found in 4:2-3. The supportive rhetorical strategy in 4:1 can be described as: "Commanding the Philippians to stand firm for the sake of the gospel". In the second phase Paul is requesting Euodia and Syntyche to be united "in the Lord", asking other members of the church to assist them in their endeavour. The verbs parakal w' and ej wt w' are "softer" than the previous command to stand firm and the strategy in 4:2-3 can be described as: "Calling on certain individuals to be united in their work for the gospel". The third and final phase differs from the previous one in that Paul is once again commanding his readers to rejoice, to be gentle, to pray and to do whatever is noble and praiseworthy. All these imperatives belong to the same rhetorical strategy, which could be described as: "Commanding the Philippians to practise certain key characteristics of the Christian life".

- Finally, the asyndeta in 4:1-9 referred to above have another important function in the section as a whole. Apart from characterising 4:1-9 and thereby identifying it as a unit for analysis, they also serve to isolate each command/request, thereby giving it individual importance in the apostle's attempt to persuade his audience (see discussion under 4.4 below).

\subsection{Philippians 4:1: commanding the Philippians to stand firm for the sake of the gospel}

In a general command, directed at all believers in Philippi, Paul writes in 4:1: "So then, (w\$te), my beloved brothers (a del $\mathrm{f}$ o i vmou agaphtoi), whom I long for (epipoghtoi), my joy and crown

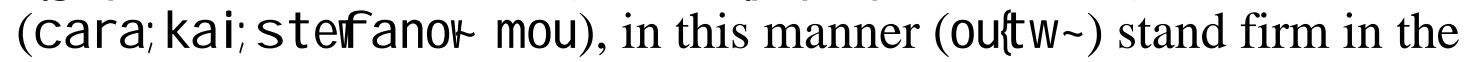
Lord (s thket e ej kuriw), beloved (agapht oi v"”. As pointed out in the discussion above, $4: 1$ is a transition verse; it reaches back as far as 1:27, where Paul urges all his readers to remain steadfast in the gospel and to do so "with one mind and spirit", and it leads into the specific appeals of 4:2-3, directed at two named women (Fee 1995:385-6). 
Of rhetorical significance is the high pitch of emotion expressed by the terms a del f oi vmou ag apht oi; ep ipoght oi, carav and; s t ef a no $\forall$. "My beloved brothers" is, of course, a much more intimate form of address than "brothers" (found in 3:1, 3:17, 4:8, etc.) and with the other terms added, the apostle expresses his deep affection for and attachment to the Philippians in a highly emotional way. The Philippians give him cause for joy (caray and pride (steffanot) - now and in future - and he longs for them (epipoghtoi), because they accepted and lived according to the gospel he brought them some twenty years ago. With this in mind, Paul commands them a second time in the letter to stand firm (s t hket e) "in the Lord" (ej kur i w), that is, in fellowship with Him and for the sake of the gospel (Müller 1976:136-7; Fee 1995:395-7).

Thus, the function of the series of endearing terms in $4: 1$ is twofold. Firstly, it shows Paul's closeness to and deep affection for the Philippians, and, secondly, it forms the basis of the appeals that follow. Based on his profound love for them and his concern for the work of the gospel, he is bound to instruct the individuals in 4:2-3. And based on that same close relationship, he can expect them to respond to his call for unity in a positive way.

In order to enhance his communication in 4:1, Paul uses the rhetorical technique of repetition with agapht oiv Being placed at the beginning and end of the series, the term emphasises the close relationship between Paul and his audience (Fee 1995:387).

\subsection{Philippians 4:2-3: calling on individuals to be united in their work for the gospel}

The two verses read: "I plead with Euodia (E updi a n parakal w) and I plead with Syntyche (kai; Sunt urhn parakalw) to agree with each other in the Lord (t 0 ; a ut $0 ; f$ r onein ej kuriw). Yes (nai), and I ask you (ejwt w'kai; sey, true companion (gnhrie suguge), help these women (sull a mbanou a ut a $i \sim$ ), who have contended at my side in the cause of the gospel (aitfine en twl euiggeliw/ sunhqlhsa moil, along with Clemens and the rest of my coworkers (s unerg wh mou), whose names are in the book of life".

Philippians 4:2-3 differs from 4:1 in two respects: it is a request and not a command, and it is directed towards individuals and not towards all believers in Philippi. Scholars differ as to the interpretation of parakal w! Is it "an express and unquestionable rebuke, telling us a great deal about the seriousness of the Philippian 
problem", as Silva (1988:221) argues; or is it an appeal to "long-time friends and co-workers, leaders in the believing community in Philippi, who have fallen in some bad times in terms of their 'doing the gospel'”, as Fee (1995:389) contends? I prefer the latter, since the context of $4: 1-3$, as well as the verbs parakal $w^{\prime}$ and ej wt $w$ ', justify a "softer" approach.

As is the case with the command to stand firm (4:1), the appeal to unity addresses a major issue in the Philippian community. The qualification en kur iw/at the and of 4:2 indicates that Paul's concern is with "doing the gospel", not with a personal dispute between two women. The appeal is necessary, because the unity of the church is at stake. This is clear from the phrase t 0; a uf 0;f r onein en kuriw. The individuals concerned should understand that their disunity was having serious repercussions for the unity of the church. Based on the special relationship between them, Paul is convinced that his appeal will not alienate the two women; on the contrary, he expects them to comply with it for the sake of the gospel.

Two issues are rhetorically significant in 4:3. The first is the change from parakal $w^{\prime}$ in $4: 2$ to the "softer" ej wt $w^{\prime}$ in 4:3. The change places Paul and his audience on the same footing. Secondly, the form of address in 4:3, namely gnhsie suruge, is equally significant. There is a question about the term $s$ uzuge. Is it a proper name, or the description of an unknown person? The majority translations (KJV, NIV, NAB, TEV, 1983 Afrikaans translation, etc.) prefer the latter. Important for our purpose, however, is that this individual is addressed as gnhsie, which means: "pertaining to possessing purported good character or quality - 'genuine, real'” (Louw and Nida 1988:675). He was clearly well-known to the Philippians and an influential member of the church. Paul addresses him with respect and reverence in order to obtain his assistance in solving the dispute.

The relative clause introduced by a i i i ne provides the reason for Paul's request: because these two women "contended at my side in the cause of the gospel, together with Clement and my other coworkers". The notion of fellowship or participation is strongly brought out in this verse. As Paul remembers individuals like Euodia, Syntyche and Clemens he recalls all the other sunergoiv who worked with him in the cause of the gospel. 
Important from a rhetorical perspective is the emphasis on "corporate responsibility" (Silva 1988:222) in addressing the problem of disunity. In the final analysis, Euodia and Syntyche need the help of the whole congregation, simply because all believers are jointly responsible for solving the problem and living the gospel in Philippi.

Paul uses the following supportive rhetorical techniques to enhance the impact of his communication in 4:2-3:

- The repetition of parakal $w^{\prime}$ in 4:2 indicates his eagerness to solve the problem and emphasises the importance of the appeal to each woman individually.

- $\quad$ By repeating the verb with each name, Paul is giving Euodia and Syntyche equal prominence without taking sides in their dispute (Thurston and Ryan 2005:140).

- $\quad$ The frequent use of the first person singular (in "I appeal", "I ask", "with me", "my co-workers") emphasises the very personal nature of his requests.

- The word naivat the beginning of $4: 3$ is a particle of confirmation or agreement, strengthening Paul's request for assistance.

- The repetition of the prefix sun- in the terms surugor, sunaqlew and sunergoivserves to highlight the notion of fellowship or participation in the cause of the gospel.

- $\quad$ The verb sunhql hs an is an athletic metaphor with the sense of "engaging side by side". Here it is used for the struggle of Paul and his co-workers for the sake of the gospel (Fee 1995:395).

To summarise: Paul's rhetorical strategy in this phase can be described as: "Calling on certain individuals to be united in their work for the gospel”. The phase is the culmination of the argument for unity that Paul has been making throughout the letter. That his concern is with unity in the work of the gospel and not with personal disputes is clear from the phrase t 0 ; a ut $0 ; f$ ronein en kuriw/at the end of verse 2 . The appeal and its expected response are based on the close relationship between himself and his readers, as spelled out in $4: 1$.

In 4:3 Paul asks a third party to mediate in the dispute. The way in which he does so is rhetorically significant: he changes from 
paraka I w' to ej wt w', thereby placing himself and the Philippians on the same footing; and he addresses his co-worker as gnhsie. These devices are persuasive in that they suggest a polite, but firm, approach to the problem.

The reason for his request is that these women contended with him in the cause of the gospel - as is the case with Clement and the other fellow-workers. They should all assist in solving the dispute, since unity is a "corporate responsibility".

Rhetorical techniques used to enhance the comunication in 4:23 are repetition, the use of the first person singular, the particle na i $v$ and the athletic metaphor sunhql hs an.

\subsection{Philippians 4:4-9: commanding the Philippians to practise certain key characteristics of the Christian life}

As indicated above, Paul's dominant rhetorical strategy in this entire section (4:1-9) can be summarised as: "Urging the Philippians to live the gospel". In the current phase (4:4-9) he achieves this by way of four commands: to rejoice, to be gentle, to pray and to live moral lives. The rhetorical framework created by these commands is now further developed by studying the way Paul argues, the types of arguments he uses and the rhetorical techniques he employs in order to achieve his goal.

Exegetes differ as to the relation between the four commands. Hendriksen (1962:196), Schenk (1984:244) and Gnilka (1976:169) regard them as closely related and explain what follows in the light of the first command (to rejoice). Following a different line of thought, Silva (1988:223-4) is also convinced that they "are not as loosely related as may appear at first blush ... and very much belong together, particularly in the context of the many problems faced by the Philippian community". The command to be gentle in $4: 5$, for example, is regarded by Silva as a reinforcement of the command to rejoice. O'Brien (1991:484) on the other hand, points out that, although there are links between joy, gentleness and prayer, Paul is not making these connections in 4:4-9. The commands are grammatically independent of each other, with no causal links between them. His motivation is based on the technique of asyndeton: “... through the use of asyndeton, the apostle's commands take on an individual importance; each is isolated and so made emphatic" (O'Brien 1991:484-5, with reference to Hawthorne 1983:177 and 183). 
I agree with O'Brien's interpretation, since the same rhetorical technique is also found in Romans 12:9-12 and 1 Thessalonica 5:1622, where instructions are listed without any links between them. The function of the asyndeta is, as pointed out, to focus on each command independently, thereby emphasising its importance.

The first command of the phase is in 4:4: "Rejoice in the Lord always (c a iret e ej kur i w/pant ot e); I say it again: rejoice ( $p$ a vin ej w', c a i wet e)". Rejoicing is a key note of the letter and now Paul is commanding them once more to be joyful. The command is repeated, because rejoicing at all times ( $p$ ant ot $e$ ) is crucial for living the gospel and an indication of how strongly Paul feels about it (Thurston and Ryan 2005:144).

The key to this rejoicing is its being en kuriw/. Only in the closest union with their Lord will the Philippians be able to experience uninterrupted joy. According to Loh and Nida (1977:127) en kuriw/should not be interpreted as the cause of their joy, but as the circumstance in which they are completely happy.

The second command is to be gentle: "Let your gentleness (epieiket) be evident to all men. The Lord is near (eggut)". The command is unconnected with the previous one, thereby isolating and emphasising it. This Christ-like attitude should be evident to all, that is, to believers and non-believers alike. By living the gospel in this way, the Philippians will have an influence on all their pagan neighbours.

In the midst of his commands in this phase Paul inserts a brief statement about the nearness of the Lord. Scholars differ with regard to the meaning of the term eg gu (which is clearly ambiguous), as well as to the function of the statement within its context. Fggu could be understood as either temporally or spatially. Most exegetes understand it as temporal, in the sense of His imminent parousia (Vincent 1961:133-4; Hendriksen 1962:194; Lightfoot 1970:160; Müller 1973:195; Loh and Nida 1977:128, and others.). Lohmeyer (1974:169) on the other hand, thinks it is an instance of intertextuality, echoing Psalms 119:151 and 145:18 (the Lord is near all who call upon Him) and should thus be understood as spatially. Although the majority of exegetes prefer a temporal interpretation (based on the context), it is unnecessary to choose between the two possibilities: the Lord could return at any time, and He is continually 
near his people to bless and to guide them (Hawthorne 1983:182; O’Brien 1991:489 and Fee 1995:407-8).

Rhetorically important is the function of the statement within the series of commands. The asyndeton indicates that it is not to be linked exclusively to what precedes or to what follows (another point of dispute among exegetes). The affirmation of the Lord's nearness has a bearing on all the commands and is "intended by the apostle to encourage his dear friends at Philippi as he called upon them to rejoice, to let their gentleness be evident to all, and not to be anxious" (O’Brien 1991:490). Knowing that their Lord is near, is intended to be a strong incentive for the Philippians to respond to all the commands in an appropriate way, thereby living the gospel they have received.

The third command consists of two rather long and complex sentences (4:6-7): "Be anxious in nothing (mh den merimnate), but in everything (a) I V ej panti) by prayer and supplication (thy proseuchy kai; thy dehsei), with thanksgiving (met a; eucaristia ) make your requests known to God (t a; ait hmat a umwh gnwrizesqu pro; t on qeom); and the peace of God (kai;h) eijhmh tou' qeou') surpassing all understanding, will guard your hearts and your minds (f rourhsei ta; kardia umwh kai; ta; nohmat a umwh) in Christ Jesus".

The two verses reflect a command-result pattern, as indicated by the consecutive $\mathrm{ka}$ i vat the beginning of 4:7: as a result of making their requests known to God, the Philippians will experience God's peace. The result could be interpreted as a promise (Fee 1995:410) and (as such) could serve to encourage the Philippians to bring all their concerns to God in prayer.

The following are also rhetorically significant:

i The command in 4:6 is unconnected with the preceding verses and thus isolated and emphasised.

ii The contrast between the negative command ("stop worrying”) and its positive counterpart ("make your requests known to God") is indicated by a I V and highlighted by mh dex and en pant i v Scholars differ as to the meaning of ej pant i v Does it denote time (in the sense of "always") or circumstance ("in every circumstance of life, in every situation")? (For a discussion, see O’Brien 1991:491-2 and Fee 1995:409). The context 
favour the latter, and the qualifications mhdem and en pant iv are thus used to emphasise the comprehensive nature of both commands: all exceptions are excluded (O’Brien 1991:491-2).

iii In 4:6 Paul lists three terms for prayer: pros euc hy ("prayer"), dehsei ("plea") and aif hma ("request"). These terms do not refer to distinct types of prayer, but signify the great importance that Paul attaches to prayer (as an antidote to anxiety) in living the gospel.

iv Hawthorne (1983:183-4) is of the opinion that the real focus of 4:6 is not on the fact that the Philippians must pray, but on the fact that they must do so "with thanksgiving" (met a; eufaristia ). Although this phrase could be combined with what precedes ("by prayer and supplication with thanksgiving") and with what follows ("with thanksgiving let your requests be known to God") - as Loh and Nida (1977:130) suggest - a commentator like Silva (1988:227-8) prefers the latter. If correct, the prepositional phrase begins a new clause and is thus emphatic, thereby justifying the importance that Hawthorne attaches to it.

The result of constant prayer is peace, the peace of God that surpasses all understanding (4:7). Scholars differ with regard to the genitive to u' qeou! is it a subjective genitive (peace that comes from God), or a descriptive genitive (that characterises the nature of God)? Hawthorne (1983:184) discusses this question at some length and concludes that it is a descriptive genitive, referring to the peace that God himself has and which the Philippians will share when they submit their anxiety to God in prayer. If correct, it has important implications for the rhetorical situation of the letter: the Philippians will not only be released from inner strife, but external strife resulting from disunity among them, will also come to an end. This will happen, since the peace of God will guard (f rourhsei) their hearts and minds in Christ Jesus. The future tense assures the promise and serves as a motivation for the Philippians to respond positively to the command in 4:6 (Müller 1973:195).

What is implied by the commands in 4:6 is that the Philippians had plenty of reasons to worry, including a lack of joy, internal unrest and disunity (see 2 above). In order to address these problems and to live the gospel, they should make their requests known to God and experience His peace that surpasses all understanding. 
The fourth command deals with moral issues and is - from a rhetorical perspective - the most interesting of them all: "Finally, brothers (a delf oi y, whatever is true ( 0 \& a es t in al hqh), whatever noble (o $\$$ a semnay, whatever just ( 0 \$ a dikaia), whatever pure (o\$a agnay, whatever acceptable ( 0 a prosfilh), whatever honourable (o a euf $h \mathrm{ma}$ ), if anything is excellent (ei [ $\mathrm{i} ; \sim$ ajet $\mathrm{h}$ ) and if anything praiseworthy ( $\mathrm{kai}$; ei[ $\mathrm{t} \mathrm{i} \sim \mathrm{ep}$ a ino ), consider these things (t a ut a logizes qe). What things you also learned (a $\mathrm{kai}$; emaqete) and received (kai; parelabete) and heard (kai; hkousate) and saw (kai; eidete) in me (ej emoiy, do these things (t a ut a pras set e), and the God of peace will be with you".

The command -result pattern of 4:6-7 is repeated in these two verses, with the result (indicated by the consecutive kaily again referring to peace. As was the case in 4:6-7, the result, (which is stronger than in 4:7, namely the God of peace) could be read as a promise that serves to encourage the Philippians to heed to Paul's commands. Both commands in verses 8-9 deal with moral issues and the two main verbs ( $\operatorname{og}$ i $z$ es qe and pra s s et $e$ ) are placed at the end of their respective sentences. The rhetorical function of this type of structure will become clear in due course.

The six plural adjectives in 4:8 are all introduced by the relative pronoun $0 \$ a$ without grammatical connectives between them, thereby emphasising each ethical quality and drawing attention to it (O’Brien 1991:503). The qualities are summarised by two singular nouns (ajet hvand epaino ), both introduced by ei[ ti . Commentators (like Loh and Nida 1977:132-3; O’Brien 1991:506; and Thurston and Ryan 2005:147) agree that the introductory eij signifies "if, as is the case; since", and does not express any doubt or uncertainty.

Two things should be noted in terms of Paul's rhetorical strategy in 4:8. The first is the origin and function of the virtue list. Commentators are not ad idem on its origin. According to Hendriksen (1962:198) the virtues have a Christian origin, as is clear from, amongst others, the reference to the "peace of God" and the fact that "these things" have been heard and seen in Paul himself (verse 9). Lohmeyer (1974:172-7), again, pointed out that nearly all the virtues in the catalogue appear in the LXX and thus have a religious origin. The majority of exegetes (Hawthorne 1983:188; Silva 1988:229; O’Brien 1991:501-2; Fee 1995:415-7), however, agree that these 
virtues belonged to the culture of Paul's day and were not at all unique to Christianity or the LXX. The apostle has taken them from a textbook of ethical instruction, in use among popular moral philosophers of his time, and used them for his purpose.

Which interpretation is to be preferred? I tend to agree with the majority of exegetes that Paul used terms from popular (especially Stoic) moral philosophy here, with which the Philippians would have felt very much at home before they became Christians. The reason for this preference is that such lists are to be found in Paul's other letters as well, where they are used with good rhetorical effect. What he does in 4:8, for example, is very similar to the way in which he uses vice and virtue lists in Galatians 5:19-24 and 6:1-10, namely to establish common ground between himself and his audience on the basis of shared knowledge (Tolmie 2005:216-7). Shared knowledge constitutes a strong argument here, since it is not necessary to convince people of virtues which they have already accepted. By listing these virtues, Paul uses their shared knowledge as an argument to persuade the Philippians to live noble lives, in accordance with the gospel.

Secondly, the way in which the sentence in 4:8 is structured is rhetorically effective. Only at the end of the verse does the main verb and its object occur: t a ut a logizes qe. The six introductory clauses, as well as the two conditional clauses summarising the virtues, are all subordinate to this main clause. The function of such a "rounded" structure is to keep the attention of the reader till the very end.

Philippians $4: 9$ is linked to verse 8 by the relative pronoun a \{ which picks up the object of I ogizes qs e, namely t a ut a. Schenk (1984:270) does not share this view, but interprets the a[ as independent of the preceding tauta, and kaivas adversative. However, the kaivin a [ kaivcannot be adversative, since it stands second in the sentence; ka i vcan only signify something in addition to what precedes: "(those things), which also" (Vincent 1961:140. See also Silva 1988:230 and O'Brien 1991:500). Important for our purpose is that the virtue list in $4: 8$, as well as the fourfold reminder in 4:9 (emaquete, parelabete, hkousate and eidete), do not contain any new information. Paul and his readers share the virtue list and in addition to that, the Philippians are well aware of the way in which he lives the gospel. By not building his argument on any 
new information, Paul is strengthening its persuasive force: it is not necessary to convince the Philippians of anything; he could simply appeal to what they already knew.

Philippians 4:8-9 resemble the command - result pattern of 4:6-7. The result, indicated by the consecutive kaivat the end of verse 9, could also be interpreted as a promise that serves to encourage the Philippians to live noble lives and to follow Paul's example.

Three issues are of rhetorical significance in 4:9. Firstly, the four verbs in 4:9a form two pairs: emaqete and parelabete, referring to what the Philippians had learned and received; and hkous a te and eidlet e, referring to what they had heard and seen in Paul (Vincent 1961:140; Müller 1973:199; Hawthorne 1983:189190; and O'Brien 1991:510-511). Such a division is (correctly) based on the meaning of the verbs: the first two draw attention to Paul's teaching, the last two to his example. Important for our purpose, however, is the placement of en ejno i vat the end of the list, thereby offering an alternative relation between the four verbs. Although the prepositional phrase strictly relates to only eidete, Hawthorne (1983:190) is of the opinion "that Paul may have deliberately placed the en emoiv ("in me") at the end of the list, not only for rhetorical effect, but to say as forcefully as possible that everything he knew and believed and taught was embodied in himself, so that those who learn, receive and hear could see what doctrine looked like in living form". This suggestion is based on Paul's conviction that the truths of the gospel must always be expressed in the life of the preacher.

Given the careful way in which Paul constructs his sentences and places key terms in his arguments, Hawthorne's interpretation is probably correct. If so, $4: 9$ as a whole could be regarded as an argument based on example - a type of argument also used in 2:5-11 and 3:17-21. This type of argument is effective, because it is easy to understand and to apply to the issue under discussion. Here Paul uses it to reinforce his instruction to Christian living. His ultimate aim is to persuade the Philippians to live lives worthy of the gospel.

Secondly, Paul uses the same technique to structure this command as the one used in 4:8. The main verb and its object ( $t$ a ut a pras s et e) appear only at the end of the sentence, thereby creating a "rounded" structure that keeps the attention of the audience till the end. 
Thirdly, both commands also have the same form: object plus imperative (t a ut a logizesqe / t a ut a pras set e). However, by changing from logizesqe to prassete, Paul intensifies his command to Christian living. This is one of the ways in which he does so - the other one being the strong instruction the Philippians have received with the four verbs strung together in verse 9 (Silva 1988:229-230).

Paul uses the following supportive rhetorical techniques to strengthen the impact of the commands in 4:4-9:

- Repetition of caivete at the beginning and end of 4:4 emphasises the command to rejoice - a keynote of the letter as a whole.

- The verb frourhsei in $4: 7$, which is a military metaphor, pictures a garrison that keeps guard over a city to maintain peace and to protect it against attacks (Louw and Nida 1977:131). The metaphor was easy to understand, since the city of Philippi was guarded by a Roman garrison at the time.

- The nounsta; kardia umwh kai;ta;nohmat a umwh in 4:7, which are separated by the article and the personal pronoun used with each of them, focus on "feeling" and "thoughts" as the two distinctive faculties of man (Vincent 1961:137).

- $\quad$ Direct address (ajelf oi y at the beginning of 4:8 is used to indicate the close relation between Paul and his readers, and to focus attention on what follows.

- $\quad$ The repetition of 0 a in an initial position in 4:8, which is technically known as epanaphora (Nida et. al. 1983:175), imparts "a stately impressiveness" and emphasises that "nothing is to be excluded from what is true, noble, just, pure, lovely and admirable” (O’Brien 1991:500).

- The lack of any connectives between the six virtues (asyndeton) "produces a vivid and impassioned effect" [O’Brien 1991:500, with reference to BDF, par 460 (3)].

- Polysyndeton with kaivin 4:9, which is the repetition of a single item in a non-structurally significant position (Nida et. al. 1983:177), is used to produce "the impression of extensiveness and abundance by means of an exhaustive summary” [O'Brien 1991:507, referring once more to BDF, par 460 (3)]. 
To summarise: The rhetorical strategy in 4:4-9 can be described as: "Commanding the Phillippians to practise certain key characteristics of the Christian life". The four commands are unconnected, thereby isolating each one and emphasising its importance. The first one is repeated, because rejoicing is a keynote of the letter and crucial for living the gospel. In order to encourage the Philippians to respond to all four commands, Paul inserts the important olkurio eg gut at the end of verse 5 .

The contrast between mhden and en pant ivemphasises the comprehensive nature of the commands in 4:6-7. Paul emphasises the importance of prayer by using three terms: pros euchy dehs i and aifhma. However, the real focus of 4:6 is probably not on prayer, but on thanksgiving, as the placement of met a ; euf a rist i at the beginning of a new clause indicates.

Tou' qeou' in 4:7 is a descriptive genitive referring to the peace that God Himself has and which the Philippians will share. By sharing it they will be released from external strife resulting from the disunity among them. The assurance is indicated by the consecutive ka i vand highlighted by the future tenses in both $4: 7$ and $4: 9$, which (as promises) serve to motivate the Philippians to adhere to Paul's commands.

In 4:8 Paul uses an argument based on shared knowledge to persuade the Philippians to live noble lives. The "rounded" structure of this and the next verse is aimed at keeping the attention of the readers till the very end. Verses 8 and 9 do not provide any new information, thereby strengthening Paul's argument by enabling him to appeal to what the Philippians already knew.

By placing en emoivat the end of the four verbs in 4:9a, Paul emphasises that everything the verbs refers to was embodied in himself, so that those who learn, receive and hear could see what doctrine looked like in living form. This argument from example is effective, because it is easy to understand and serves to reinforce Paul's instruction to Christian living.

Supportive rhetorical techniques in 4:4-9 include direct address, epanaphora, asyndeton and polysyndeton. 


\section{CONCLUSION}

The aim of this article was to prove that Paul's rhetorical strategy in 4:1-9 can be reconstructed from the text itself, without forcing rhetorical categories on the letter.

Philippians 4:1-9 is demarcated as a unit for analysis by rhetorical considerations. Paul's dominant rhetorical strategy in this section could be described as: "Urging the Philippians to live the gospel". In doing so, he uses several commands, appeals and promises. In analysing these, the focus was on the way he argues, on the types of arguments he uses and on rhetorical techniques that could enhance the impact of his communication. Examples of arguments based on shared knowledge and example have been identified, while supportive techniques like direct address, various kinds of repetition, striking metaphors, asyndeton and the emphatic placement of terms all contribute to the impact of his communication and serve to persuade his readers to live the gospel.

\section{Consulted literature}

Alexander, L 1995. Hellenistic letter-forms and the structure of Philippians. In: The Pauline Writings. Edited by S E Porter and C G Evans. Sheffield: Sheffield Academic Press, 232-246.

Betz, H D 1979. Galatians. A commentary of Paul's Letter to the Churches in Galatia. Philadelphia: Fortress.

Black, D A 1995. The Discourse Structure of Philippians: A Study in Textlinguistics. Nov Test 37,16-49.

Bloomquist, L G 1993. The Function of Suffering in Philippians. JSNT Sup 78. Sheffield.

Brown, R E 1997. An Introduction to the New Testament: Letter to the Philippians. The Anchor Bible Reference Library. New York, London, Toronto, Sydney, Auckland; Doubleday.

Fee, G P 1995. Paul's Letter to the Philippians. The New International Commentary on the New Testament. Michigan, Grand Rapids: WB Eerdmans Publishing Company.

Fitzgerald, J T 1996 (ed.). "Philippians in the Light of Some Ancient Discussions on Friendship", in Friendship, Flattery, and Frankness of Speech: Studies on Friendship in the New Testament World. Nov Test Suppl 82. Leiden: E J Brill, 141-160.

Gnilka, J 1976. Der Philipperbrief. Basel: Herder.

Hawthorne, G F 1983. Philippians. Word Biblical Commentary, Vol 43. Waco, Texas: Word.

Hendriksen, W 1962. PhiIlppians. New Testament Commentary. Grand Rapids: Baker.

Lightfoot, J B 1970. St Paul's Epistle to the Philippians. Grand Rapids: Zondervan. Reprint. 
Loh, I J \& Nida E A 1977. A Translators Handbook on Pauls' Letter to the Philippians. Helps for Translators. Vol 19. Stuttgart: United Bible Societies.

Lohmeyer, E 1974. Der Brief an die Philipper. Göttingen: Vandenhoeck \& Ruprecht.

Louw, J P \& Nida E A 1988. Greek-English Lexicon of the New Testament Based on Semantic Domains. New York: United Bible Soceities.

Marshall, P 1987. Enmity in Corinth. WUNT 2/23. Tübingen.

Matter, H M 1976. De Brief van Paulus aan de Philippenzen en de Brief aan Philemon. Commentaar op het Nieuwe Testament. Kampen: JH Kok.

Müller, J J 1976. The Epistles of Paul to the Philippians and Philemon. The New Testament. Michigan, Grand Rapids: WB Eerdmans Publishing Company.

Müller, U B 1973. Der Brief des Paulus an die Philipper. Theologischer Handkommentar zum Neuen Testament. Leipzig: Evangelische Verlagsanstalt.

Nida, E A, Louw J P, Snyman A H, Cronje J v W 1983. Style and discourse. Cape Town: United Bible Societies.

Osiek, C 2000. Philippians. Philemon. Abingdon New Testament Commentaries. Nashville: Abingdon Press.

O’Brien, P T 1991. The Epistle to the Philippians. Michigan, Grand Rapids: WB Eerdmans Publishing Company.

Schenk, W 1984. Die Philipperbrief des Paulus. Kommentar. Stuttgart: W Kohlhammer.

Silva, M 1988. Philippians, in Barker, K (ed.). The Wycliffe Exegetical Commentary. Chicago: Moody Press.

Thurston, B B \& Ryan J M 2005. 'Philippians and Philemon', in Sacra Pagina Series, Vol 10 D J Harrington (ed.). Collegeville, Minnesota: Liturgical Press.

Stowers, S K 1991. Friends and Enemies in the Politics of Heaven: Reading Theology in Philippians, in Bassler, J M (ed.). Pauline Theology. Mineapolis, 105-121.

Tolmie, D F 2000. "Paulus se retoriese strategie in Galasiërs 1:1-10. Acta Theologica 20/2, 122-137.

-, 2005. Persuading the Galatians. A Text-Centred Rhetorical Analysis of a Pauline Letter (WUNT 2/190). Tübingen: Mohr Siebeck.

Vincent, M R 1961. The Epistles to the Philippians and to Philemon. A critical and exegetical commentary. Edinburgh: T\&T Clark.

Watson, D F 1988. “A Rhetorical Analysis of Philippians and its Implications for the Unity Question”. Novum Testamentum 30, 57-88.

White, L M 1990. Morality between Two Worlds: A Paradigm of Friendship in Philippians, in D L Bach, E Ferguson and W A Meeks (eds.). Greeks, Romans and Christians. Essays in Honor of Abraham $J$ Malherbe. Minneapolis, 201-215.

Witherington, B III 1994. Friendship and Finances in Philippi: The Letter of Paul to the Philippians. The New Testament in Context. Valley Forge, P A: Trinity Press International. 